\title{
Synthesis, characterization, spectroscopic and crystallographic investigation of metal complexes of N-benzyl-N-nitrosohydroxylamine
}

\author{
Olga Kovalchukova ${ }^{1}$, Ali Sheikh Bostanabad ${ }^{1}$, Vladimir Sergienko ${ }^{2}$, Irina Polyakova ${ }^{2}$ Igor Zyuzin $^{3}$, \\ Svetlana Strashnova ${ }^{1}$ \\ ${ }^{1}$ Peoples' Friendship University of Russia, Moscow, Russia \\ ${ }^{2}$ Institute of General and Inorganic Chemistry, Russian Academy of Sciences, Moscow, Russia \\ ${ }^{3}$ Institute of Problems of Chemical Physics, Russian Academy of Sciences, Chernogolovka, Russia \\ Email: okovalchukova@mail.ru
}

Received 1 November 2012; revised 10 December 2012; accepted 22 December 2012

\begin{abstract}
New metal complexes of N-benzyl-N-nitrosohy-droxylamine (BNHA) are isolated and characterized by elemental analysis, IR and UV-VIS spectroscopy. Spectrophotometric titration of aqueous solutions of BNHA by salts of some transition metals allowed to calculate the composition and formation constants of the metal complexes. The crystal structure of $\mathrm{Cu}$ $(\mathrm{BNHA})_{2}$ is studied by $\mathrm{X}$-ray diffraction. The $\mathrm{Cu}$ atom is coordinated by four $\mathrm{O}$ atoms of two bidentate ligands, which close 5-membered chelate rings. The N-O (1.306 $\AA-1.320 \AA)$ and N-N (1.274 $\AA$ and $1.275 \AA)$ bond lengths indicate that $\pi$ electrons are delocalized over the chelating groups. Complexes form stacks with intermolecular $\mathrm{Cu}$.... contacts equal to $3.118 \AA$ and $3.306 \AA$.
\end{abstract}

Keywords: N-Benzyl-N-Nitrosohydroxylamine; BNHA; Potassium Salt; Complex Compounds; IR; UV-Visible; Single Crystal X-Ray Diffraction; Formation Constants

\section{INTRODUCTION}

The feature of chelate-forming derivatives of N-nitrosohydroxylamines is the possibility to form stable complexes with the metallic ions of various natures (for example, $\mathrm{Al}$ and $\mathrm{Pd}$ ).

The ammonium salt of N-nitroso-N-phenylhydroxylamine, is a well known (as cupferron) analytical reagent and it was very popular especially during the classical period of analytical chemistry [1-3]. This ligand is known to form complexes with many metals but only few of them have been structurally characterized [4-15].

Recently it was shown that many ortho-substituted $\mathrm{N}$-nitroso-N-oxybenzenamines are good NO donors for both in vitro and in vivo assays [16]. As the major bio- logical functions of NO include controlling blood pressure, smoothing muscle tone and platelet aggregation, and participating in neuronal synaptic transmission, Thus, the development of new substances which are potential NO donors and studies of their structure and properties are current challenges facing medicinal and synthetic chemists.

In addition, cupferron is a biologically active compound, known to display carcinogenic, genotoxic, mutagenic and DNA-damaging effects $[17,18]$. The knowledge of the chemistry of cupferron and its analogues containing N-nitrosohydroxylamine fragments could contribute to a better understanding of the interaction of nitrogen oxide with metal centers of biologically important species.

Here we report the isolation and characterization of some transition metal complexes with N-benzyl-N-nitrosohy-droxylamine (BNHA).

\section{EXPERIMENTAL}

\subsection{Measurements}

The electronic spectra in the $200-800 \mathrm{~nm}$ range were obtained on a Varian spectrophotometer "Cary 50 scan", using aqueous $10^{-4} \mathrm{M}$ solutions. IR spectra were recorded in $\mathrm{KBr}$ on a Varian "Excalibur HE 3100" FT spectrophotometer. Single crystal was characterized by a Bruker APEX II diffractometer. All the chemicals are commercially available and they were used without further purification. All the solvents were dried using standard methods before use.

\subsection{Synthesis of $\mathrm{K}(\mathrm{BNHA})$ and Transition Metal Complexes}

$\mathrm{K}(\mathrm{BNHA})$ and $\mathrm{Cu}(\mathrm{BNHA})_{2}$. The synthesis was performed according to the procedure described in [19]. A solution of benzylmagnesium chloride was prepared 
from magnesium (24.3 g, $1 \mathrm{~mol})$ and benzyl chloride $(126.7 \mathrm{~g}, 1 \mathrm{~mol})$ in the dry $\mathrm{Et}_{2} \mathrm{O}(800 \mathrm{~mL})$. The $\mathrm{NO}$ gas was bubbled through the solution under vigorous stirring and cooling at such a rate that NO was almost entirely absorbed. The NO flow rate and the degree of its absorbance were controlled by the comparison of the rate of NO bubbling through the bubble vessel filled by $\mathrm{NaOH}$ at the outlet of the reactional vessel. The reaction mixture temperature was maintained in the range $-20^{\circ} \mathrm{C}$ $-30^{\circ} \mathrm{C}$. A pasty solid was separated and encumbered stirring. After the period of a rapid NO absorption $(1 \mathrm{~h})$, stirring was continued in an NO atmosphere for $0.5 \mathrm{~h}$ until the NO absorption was completed, with a gradual increase in temperature to $0^{\circ} \mathrm{C}$. The reaction mixture was purged with Ar to avoid site reactions involving both NO and the Grignard reagent, cooled to $-10^{\circ} \mathrm{C}$, and then a mixture of $\mathrm{MeOH}(50 \mathrm{~mL})$ and $\mathrm{Et}_{2} \mathrm{O}(50 \mathrm{~mL})$ was gradually added. The reaction mixture was poured into $700 \mathrm{~mL}$ of water, acidified with $5 \mathrm{M} \mathrm{HCl}$, the ethereal layer was separated, and the aqueous layer was extracted with $\mathrm{Et}_{2} \mathrm{O}(100 \mathrm{~mL} \times 3)$. The combined extracts were washed with an excess of $10 \% \mathrm{KOH}$. The aqueous layer was neutralized with $5 \mathrm{M} \mathrm{HCl}$ until $\mathrm{pH} 4$. The precipitate of N-benzyl-N-nitrosohydroxylamine was washed with water. The wet product was dissolved in the appropriate quantity of $10 \% \mathrm{KOH}$, so that the $\mathrm{pH}$ value reached $8-9$. The mixture was concentrated in vacuo, the residue (108 g) was crystallized from EtOH $(200 \mathrm{~mL})$, and dried in air.

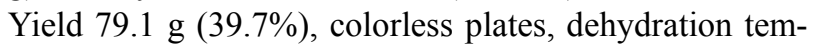
perature $110^{\circ} \mathrm{C}-115^{\circ} \mathrm{C}$, m.p. $211^{\circ} \mathrm{C}-214^{\circ} \mathrm{C}$ (dec.). Upon heating $(1 \mathrm{~h})$ in vacuo at $110^{\circ} \mathrm{C}-145^{\circ} \mathrm{C}$, a sample of the air-dried salt (10.5547 g) lost $0.4838 \mathrm{~g}$, i.e., $0.507 \mathrm{~mol}$ of $\mathrm{H}_{2} \mathrm{O}$ per one mol of the hydrated salt was removed. Filter liquor was concentrated to $50 \mathrm{~mL}$, and the additional air-dried product (14.2 g) was precipitated with $\mathrm{Et}_{2} \mathrm{O}$ $(250 \mathrm{~mL})$. The overall yield of K(BNHA) was $93.3 \mathrm{~g}$ $(46.8 \%)$. The treatment of the combined filtrate and wash liquors with $\mathrm{CuSO}_{4}$ additionally gave $9.1 \mathrm{~g}(5 \%)$ of $\mathrm{Cu}(\mathrm{BNHA})_{2}$ (m.p. $157^{\circ} \mathrm{C}-158^{\circ} \mathrm{C}$ (dec.)). The overall yield of $\mathrm{K}(\mathrm{BNHA})$ and $\mathrm{Cu}(\mathrm{BNHA})_{2} 51.8 \%$.

\subsection{Transition Metal Complexes of BNHA}

The above mentioned complexes were prepared by the reaction of the corresponding metal chloride with K(BNHA). In a typical reaction, an aqueous solution containing 1 mmol of $\mathrm{MCl}_{2} \cdot \mathrm{xH}_{2} \mathrm{O}$ was slowly mixed with $2 \mathrm{mmol}$ of the K(BNHA) under vigorous stirring. The obtained precipitates were collected and re-crystallized from ethanol. Yields 50\% - 70\%.

The formulae of the obtained complexes are derived from the elemental analysis and presented in the Table 1.

\subsection{Electronic Spectroscopic Measurements}

Spectrophotometric titration of solutions of K(BNHA) with the solutions of metal salts in water was carried out in neutral and alkaline media. Based on the results of titration, the saturation curves were drawn for several wavelengths, and the metal-to-ligand ratios were calculated. The formation constants of metal complexes were determined by the procedure described by Beck \& Nadypal [20].

\subsection{X-Ray Data Collection and Structure Determination}

Light blue needles of $\mathrm{Cu}(\mathrm{BNHA})_{2}$ suitable for X-ray data collection were obtained while re-crystallisation from ethanol. The diffraction data were collected on a Bruker APEX-II CCD diffractometer at room temperature and processed using the Bruker software [21]. The structure was solved by the direct method. The positions of the hydrogen atoms were calculated. The non-hydrogen atoms were refined in the anisotropic approximation, and the hydrogen atoms were refined within the riding model.

Table 1. Chemical analysis (calculated/observed) and empirical formulae of the isolated complexes.

\begin{tabular}{cccccccc}
\hline No. & Structure & Formula & $\% \mathrm{M}$ & $\% \mathrm{C}$ & $\% \mathrm{H}$ & $\% \mathrm{~N}$ & $\mathrm{M}$ \\
\hline 1 & $\mathrm{~K}(\mathrm{BNHA})$ & $\mathrm{C}_{7} \mathrm{H}_{7} \mathrm{KN}_{2} \mathrm{O}_{2}$ & & $44.19 / 44.23$ & $3.71 / 3.44$ & $14.73 / 14.92$ & 190.24 \\
2 & $\mathrm{Cu}(\mathrm{BNHA})_{2}{ }^{1}$ & $\mathrm{C}_{14} \mathrm{H}_{14} \mathrm{CuN}_{4} \mathrm{O}_{4}$ & $17.37 / 17.08$ & $45.96 / 45.25$ & $3.86 / 3.78$ & $15.31 / 15.44$ & 365.84 \\
3 & $\mathrm{Co}(\mathrm{BNHA})_{2} \cdot 4 \mathrm{H}_{2} \mathrm{O}$ & $\mathrm{C}_{14} \mathrm{H}_{22} \mathrm{CoN}_{4} \mathrm{O}_{8}$ & $13.60 / 13.78$ & $38.81 / 38.61$ & $5.12 / 4.88$ & $12.93 / 12.45$ & 433.28 \\
4 & $\mathrm{Ni}(\mathrm{BNHA})_{2} \cdot 3 \mathrm{H}_{2} \mathrm{O}$ & $\mathrm{C}_{14} \mathrm{H}_{20} \mathrm{~N}_{4} \mathrm{NiO}_{7}$ & $14.14 / 14.45$ & $40.52 / 41.08$ & $4.86 / 4.39$ & $13.50 / 13.37$ & 415.03 \\
5 & $\mathrm{~Pb}(\mathrm{BNHA})_{2}$ & $\mathrm{C}_{14} \mathrm{H}_{14} \mathrm{~N}_{4} \mathrm{O}_{4} \mathrm{~Pb}$ & $40.67 / 40.33$ & $33.00 / 33.19$ & $2.77 / 2.57$ & $11.00 / 10.98$ & 504.49 \\
6 & $\mathrm{Sn}(\mathrm{BNHA})_{2} \cdot 3 \mathrm{H}_{2} \mathrm{O}$ & $\mathrm{C}_{14} \mathrm{H}_{20} \mathrm{~N}_{4} \mathrm{O}_{7} \mathrm{Sn}$ & $24.99 / 25.12$ & $35.40 / 35.59$ & $4.24 / 3.90$ & $11.29 / 11.61$ & 475.03 \\
7 & $\mathrm{La}(\mathrm{BNHA})_{3} \cdot 2 \mathrm{H}_{2} \mathrm{O}$ & $\mathrm{C}_{21} \mathrm{H}_{25} \mathrm{LaN}_{6} \mathrm{O}_{8}$ & $22.11 / 22.38$ & $40.11 / 40.29$ & $4.01 / 3.33$ & $13.37 / 12.94$ & 628.37 \\
8 & $\mathrm{Cr}(\mathrm{BNHA})_{3} \cdot 2 \mathrm{H}_{2} \mathrm{O}$ & $\mathrm{C}_{21} \mathrm{H}_{25} \mathrm{CrN}_{6} \mathrm{O}_{8}$ & $9.60 / 9.41$ & $46.58 / 46.08$ & $4.65 / 4.21$ & $15.52 / 15.87$ & 541.46 \\
9 & $\mathrm{Zn}(\mathrm{BNHA}) \mathrm{Cl}^{2} \cdot 4 \mathrm{H}_{2} \mathrm{O}^{2}$ & $\mathrm{C}_{7} \mathrm{H}_{15} \mathrm{ClN}_{2} \mathrm{O}_{6} \mathrm{Zn}$ & $20.18 / 20.55$ & $25.95 / 25.36$ & $4.67 / 4.82$ & $8.65 / 8.24$ & 324.04 \\
\hline
\end{tabular}

${ }^{1}$ M.p. $157^{\circ} \mathrm{C}$ (dec.) [19]. ${ }^{2}$ For Cl: $10.94 / 11.05$. 
Structure solution and refinement were performed using the SHELX97 program package [22]. Crystal data and details of data collection and structure refinement are given in Table 2. Selected bond lengths and angles are listed in Table 3.

\section{RESULTS AND DISCUSSION}

\subsection{Electronic Spectra}

The electronic absorption spectrum of K(BNHA) (Figure 1)

Table 2. Crystal data and details of data collection and structure refinement for $\mathrm{Cu}(\mathrm{BNHA})_{2}$.

\begin{tabular}{|c|c|}
\hline Empirical formula & $\mathrm{C}_{14} \mathrm{H}_{14} \mathrm{CuN}_{4} \mathrm{O}_{4}$ \\
\hline Formula weight & 365.83 \\
\hline Temperature (K) & $296(2)$ \\
\hline Radiation, $\lambda(\AA)$ & $\operatorname{Mo} K_{\alpha}, 0.71073$ \\
\hline Crystal system, space group & Monoclinic, $\mathrm{P} 2{ }_{1} / \mathrm{n}$ \\
\hline$a(\AA)$ & $11.521(2)$ \\
\hline$b(\AA)$ & $4.6883(8)$ \\
\hline$c(\AA)$ & $28.979(5)$ \\
\hline$\beta\left({ }^{\circ}\right)$ & $100.486(3)$ \\
\hline Volume $\left(\AA^{3}\right)$ & $1539.0(5)$ \\
\hline Z & 4 \\
\hline $\mathrm{D}_{\text {calc }}\left(\mathrm{Mg} / \mathrm{m}^{3}\right)$ & 1.579 \\
\hline $\mathrm{F}(000)$ & 748 \\
\hline Crystal size (mm) & $0.64^{*} 0.03^{*} 0.02$ \\
\hline Absorption coefficient $\left(\mathrm{mm}^{-1}\right)$ & 1.445 \\
\hline Theta range for data collection (deg) & $2.54-28.46$ \\
\hline Limiting indices & $\begin{array}{c}-15 \leq \mathrm{h} \leq 15,-6 \leq \mathrm{k} \leq 6 \\
-37 \leq 1 \leq 38\end{array}$ \\
\hline Reflections collected /unique $\left[\mathrm{R}_{\text {int }}\right]$ & $15423 / 3892[0.0461]$ \\
\hline Completeness to $\theta=28.46$ & $99.9 \%$ \\
\hline Absorption correction & Semi-empirical from equivalents \\
\hline Max. and min. transmission & 0.7457 and 0.6487 \\
\hline Refinement method & Full-matrix least-squares on $\mathrm{F}^{2}$ \\
\hline Data/ restraints/parameters & $3892 / 0 / 208$ \\
\hline Goodness-of-fit on $\mathrm{F}^{2}$ & 1.024 \\
\hline Final $\mathrm{R}$ indices $[\mathrm{I}>2 \sigma(\mathrm{I})]$ & $\mathrm{R} 1=0.0432, \mathrm{wR} 2=0.0922$ \\
\hline $\mathrm{R}$ indices (all data) & $\mathrm{R} 1=0.0831, \mathrm{wR} 2=0.1067$ \\
\hline Largest diff. peak and hole, e $\AA^{-3}$ & 0.424 and -0.247 \\
\hline
\end{tabular}

Table 3. Selected bond lengths $\mathrm{d}(\hat{A})$ and angles $\omega\left(^{\circ}\right)$ in $\mathrm{Cu}(\mathrm{BNHA})_{2}$.

\begin{tabular}{cccc}
\hline Bond, angle & $\mathrm{d}, \omega$ & Bond, angle & $\mathrm{d}, \omega$ \\
\hline $\mathrm{Cu}(1)-\mathrm{O}(1)$ & $1.9138(18)$ & $\mathrm{Cu}(1)-\mathrm{O}(3)$ & $1.896(2)$ \\
$\mathrm{Cu}(1)-\mathrm{O}(2)$ & $1.921(2)$ & $\mathrm{Cu}(1)-\mathrm{O}(4)$ & $1.905(2)$ \\
$\mathrm{Cu}(1)-\mathrm{N}(2)^{a}$ & $3.306(2)$ & $\mathrm{Cu}(1)-\mathrm{N}(4)^{b}$ & $3.118(3)$ \\
$\mathrm{O}(1)-\mathrm{N}(1)$ & $1.319(3)$ & $\mathrm{O}(3)-\mathrm{N}(3)$ & $1.312(3)$ \\
$\mathrm{O}(2)-\mathrm{N}(2)$ & $1.306(3)$ & $\mathrm{O}(4)-\mathrm{N}(4)$ & $1.320(3)$ \\
$\mathrm{N}(1)-\mathrm{N}(2)$ & $1.275(3)$ & $\mathrm{N}(3)-\mathrm{N}(4)$ & $1.274(3)$ \\
$\mathrm{N}(1)-\mathrm{C}(7)$ & $1.469(3)$ & $\mathrm{N}(3)-\mathrm{C}(14)$ & $1.476(3)$ \\
$\mathrm{O}(1) \mathrm{Cu}(1) \mathrm{O}(2)$ & $82.30(8)$ & $\mathrm{O}(3) \mathrm{Cu}(1) \mathrm{O}(4)$ & $82.59(9)$ \\
$\mathrm{N}(2)^{a} \mathrm{Cu}(1) \mathrm{N}(4)^{b}$ & $177.87(6)$ & & \\
$\mathrm{N}(1) \mathrm{O}(1) \mathrm{Cu}(1)$ & $107.49(15)$ & $\mathrm{N}(3) \mathrm{O}(3) \mathrm{Cu}(1)$ & $107.83(15)$ \\
$\mathrm{N}(2) \mathrm{O}(2) \mathrm{Cu}(1)$ & $113.29(16)$ & $\mathrm{N}(4) \mathrm{O}(4) \mathrm{Cu}(1)$ & $112.72(16)$ \\
$\mathrm{O}(1) \mathrm{N}(1) \mathrm{N}(2)$ & $123.9(2)$ & $\mathrm{O}(3) \mathrm{N}(3) \mathrm{N}(4)$ & $123.5(2)$ \\
$\mathrm{N}(1) \mathrm{N}(2) \mathrm{O}(2)$ & $113.0(2)$ & $\mathrm{N}(3) \mathrm{N}(4) \mathrm{O}(4)$ & $112.6(2)$ \\
\hline
\end{tabular}

${ }^{a} \mathrm{x}, \mathrm{y}+1, \mathrm{z} ;{ }^{b} \mathrm{x}, \mathrm{y}-1, \mathrm{z}$.

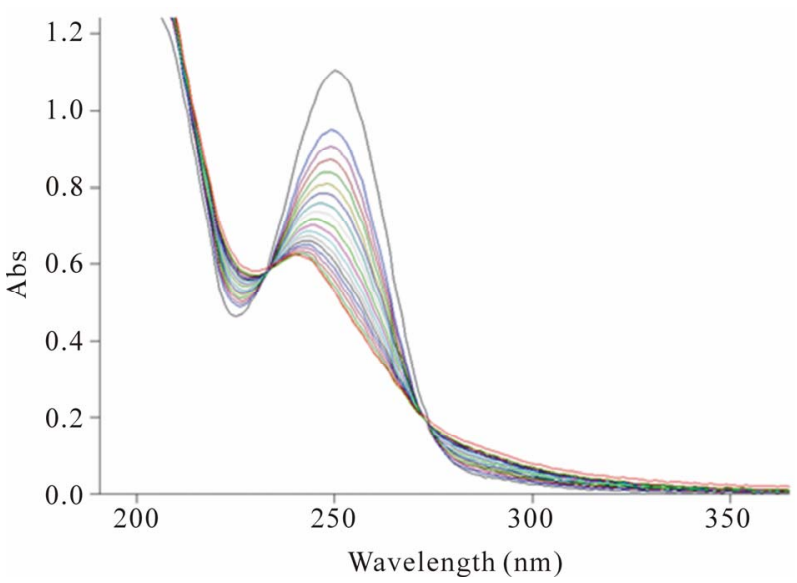

Figure 1. Spectrophotometric titration of an aqueous solution of $\mathrm{K}(\mathrm{BNHA})\left(10^{-4} \mathrm{M}\right)$ by the solution of $\mathrm{CuCl}_{2}\left(10^{-2} \mathrm{M}\right)$.

is characterized by one wide absorption band in the range $230 \mathrm{~nm}-260 \mathrm{~nm}$ with the $\lambda_{\max } 252 \mathrm{~nm}(\log \varepsilon 4.06)$.

The addition of metal salts to the solutions of K(BNHA) provokes the hypsochromic shift and decrease in intensity of the ligand absorption band which indicates the change of the electronic structures of the organic anions due to their complexation and formation of coordinate bonds of a co-valent character. $\Delta \lambda_{\max } 1-19 \mathrm{~nm}$. The presence of isobestic points in the spectra indicates the reversible equilibria in the "ligand-complex" systems. The metal-to-ligand ratio and formation constants of the complexws in aqueous solutions are presented in the Table 4.

As the K-BNHA bonds may be considered to be of 
Table 4. Composition $\left(\mathrm{ML}_{\mathrm{n}}\right)$ and stability constants $(\beta)$ of some metal complexes of BNHA in aqueous solutions and their absorbtion maxima $\left(\lambda_{\max }, \mathrm{nm}\right)$.

\begin{tabular}{cccc}
\hline Metal ion & $n$ & $\beta$ & $\lambda_{\max }, \mathrm{nm}(\log \varepsilon)$ \\
\hline $\mathrm{Mn}^{2+}$ & 2 & $6.82 \times 10^{11}$ & $249(3.87)$ \\
$\mathrm{Co}^{2+}$ & 2 & $2.67 \times 10^{10}$ & $245(3.84)$ \\
$\mathrm{Ni}^{2+}$ & 2 & $7.51 \times 10^{9}$ & $245(3.73)$ \\
$\mathrm{Cu}^{2+}$ & 2 & $3.43 \times 10^{8}$ & $238(3.80)$ \\
$\mathrm{Zn}^{2+}$ & 2 & $2.3 \times 10^{11}$ & $242(3.89)$ \\
$\mathrm{Cd}^{2+}$ & 2 & $4.46 \times 10^{11}$ & $246(3.96)$ \\
$\mathrm{Pb}^{2+}$ & 2 & $3.62 \times 10^{10}$ & $248(3.92)$ \\
$\mathrm{Ba}^{2+}$ & 2 & $7.45 \times 10^{10}$ & $251(3.93)$ \\
$\mathrm{Al}^{3+}$ & 3 & $4.73 \times 10^{14}$ & $233(3.73)$ \\
$\mathrm{Cr}^{3+}$ & 3 & $3.22 \times 10^{14}$ & $243(3.84)$ \\
$\mathrm{La}^{3+}$ & 3 & $1.28 \times 10^{17}$ & $245(3.94)$ \\
$\mathrm{Sm}^{3+}$ & 3 & $1.03 \times 10^{15}$ & $243(3.89)$ \\
$\mathrm{Eu}^{3+}$ & 3 & $8.95 \times 10^{15}$ & $242(3.92)$ \\
$\mathrm{Er}^{3+}$ & 3 & $1.03 \times 10^{15}$ & $242(3.92)$ \\
& & &
\end{tabular}

$100 \%$ ionic character, the $\Delta \lambda_{\max }$ value may indicate the increase in the degree of co-valency of M-BNHA interaction. Thus, from the data of the Table 4 it is evident that among divalent ions of the metals of the 1st transition series, the degree of co-valency of metal-to-ligand interaction changes as following: $\mathrm{Mn}^{2+}<\mathrm{Co}^{2+}=\mathrm{Ni}^{2+}<$ $\mathrm{Cu}^{2+}>\mathrm{Zn}^{2+}$. The Al-BNHA interactions possess the most covalent character as well as $\mathrm{Ba}^{2+}$ forms the coordinate bonds of almost $100 \%$ of ionicity.

\subsection{IR Spectra}

The major IR absorption bands of $\mathrm{K}(\mathrm{BNHA})$ and its $\mathrm{Cu}$ (II) and $\mathrm{Co}(\mathrm{II})$ complexes are presented in the Table 5.

The assignments of the various absorption bands in $\mathrm{K}$ (BNHA) and the transitional metal complexes were performed according to N. Thakur et al. [23] for cupferron and metal cupferrates. It is shown that on complex formation NO stretching frequencies are lowered and the deformation frequencies increased while the $\mathrm{C}-\mathrm{N}$ and $\mathrm{N}-\mathrm{N}$ stretching frequencies are not very much altered, indicating that the complex formation takes place through the oxygen of the $\mathrm{NO}$ groups.

\subsection{Crystal Structure of $\mathrm{Cu}(\mathrm{BNHA})_{2}$}

The copper atom has a nearly planar square coordination formed by oxygen atoms of two BNHA-ligands, which close 5-membered ONNOCu chelate rings (Figure 2).
The $\mathrm{Cu}(1)$ atom lies in the plane of the $\mathrm{O}(1) \mathrm{N}(1)$ $\mathrm{N}(2) \mathrm{O}(2)$ fragment (its deviation is $0.022 \AA$ ) and deviates from the $\mathrm{O}(3) \mathrm{N}(3) \mathrm{N}(4) \mathrm{O}(4)$ plane by $0.194 \AA$. In both BGA-molecules, the planar $\mathrm{O}_{2} \mathrm{~N}_{2} \mathrm{CH}_{2}$ and $\mathrm{PhCH}_{2}$ fragments lie in approximately perpendicular planes (the dihedral angles are $93.3^{\circ}$ and $109.9^{\circ}$ ). The phenyl rings of the two NBHA-molecules are bent in opposite directions with respect to the coordination plane and form an angle of $139.4^{\circ}$ with each other. The geometric parameters of the NBHA-ligands in $\mathrm{Cu}(\mathrm{BNHA})_{2}$ are close to those in $\mathrm{Zr}$ (cp)2(BNHA) [24], which is the only compound of NBHA found in the Cambridge Structural Database (version 5.33). Bond lengths (Table 3) suggest that $\pi$ electrons are delocalized over the ONNO chelating groups. The difference between the N-O bond lengths is insignificant, and the N-N bond lengths are close to the double-bond type [25]. This suggests an important contribution of the $-\mathrm{O}-\mathrm{N}+(\mathrm{R})=\mathrm{N}-\mathrm{O}$-canonical form. $\mathrm{Cu}$ $(\mathrm{BNHA})_{2}$ complexes are packed in stacks running along the $\mathrm{b}$ axis (Figure 3). In a stack, atoms N(2) and N(4) of neighboring complexes approach the $\mathrm{Cu}(1)$ atom by 3.306 (2) and 3.118 (3) $\AA$, respectively, thus completing its coordination to an extremely elongated tetragonal bipyramid.

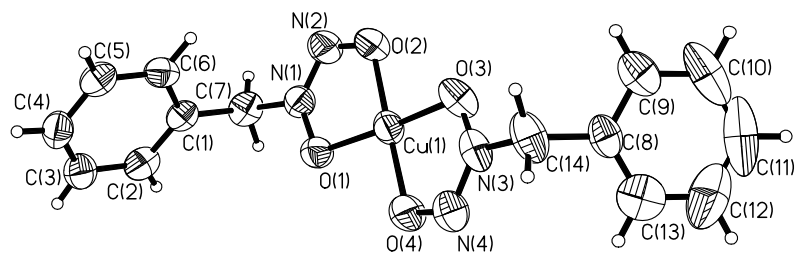

Figure 2. Molecular structure of $\mathrm{Cu}(\mathrm{BNHA})_{2}$. The thermal ellipsoids are shown at the $50 \%$ probability level.

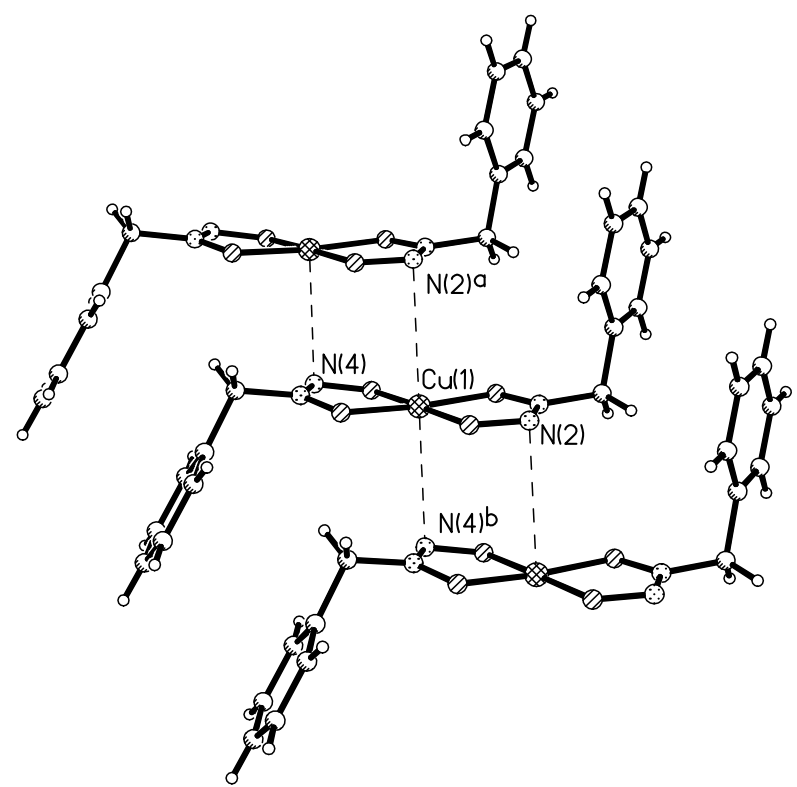

Figure 3. Mutual arrangement of neighboring $\mathrm{Cu}(\mathrm{BNHA})_{2}$ complexes in a stack. 
Table 5. Frequencies $\left(\mathrm{cm}^{-1}\right)$ and band assignments in K(BNHA) and some transition metal complexes.

\begin{tabular}{|c|c|c|c|}
\hline $\mathrm{K}(\mathrm{BNHA})$ & $\mathrm{Cu}(\mathrm{BNHA})_{2}$ & $\mathrm{Co}(\mathrm{BNHA})_{2} \cdot 4 \mathrm{H}_{2} \mathrm{O}$ & Assignment \\
\hline 3418 & 3417 & 3345 & $\begin{array}{l}\mathrm{C}-\mathrm{H} \text { stretching } \\
\text { vibration }\end{array}$ \\
\hline 3150 & 3120 & 3243 & $\begin{array}{l}\text { N-H strtching } \\
\text { vibration }\end{array}$ \\
\hline 1650 & 1633 & 1646 & $\begin{array}{l}\mathrm{C}=\mathrm{C} \text { ring } \\
\text { stretching } \\
\text { vibration }\end{array}$ \\
\hline 1434 & 1417 & 1425 & $\begin{array}{l}\text { C-N stretching } \\
\text { vibration }\end{array}$ \\
\hline 1397 & 1344 & 1395 & $\begin{array}{l}\text { NN stretching } \\
\text { vibration }\end{array}$ \\
\hline 1231 & 1214 & 1222 & $\begin{array}{l}\text { NO stretching } \\
\text { vibration }\end{array}$ \\
\hline 1145 & 1149 & 1145 & $\begin{array}{c}\text { C-N ring } \\
\text { in-plane } \\
\text { vibration }\end{array}$ \\
\hline 961 & 940 & 929 & Ring vibration \\
\hline 784 & 783 & 783 & $\begin{array}{l}\mathrm{C}-\mathrm{H} \text { ring out of } \\
\text { plane vibration }\end{array}$ \\
\hline 705 & 717 & 707 & $\begin{array}{l}\mathrm{C}=\mathrm{C} \text { ring out of } \\
\text { plane vibration }\end{array}$ \\
\hline
\end{tabular}

\section{CONCLUSION}

The N-benzyl-N-nitrosohydroxylamine (BNHA) ligand coordinates metal ions by two oxygen atoms. The bonding of the ligands to metal ions is confirmed by spectroscopic and single-crystal X-ray diffraction studies. The composition and the formation constants of the complexes in aqueous solutions were determined by UV spectroscopic titration.

\section{SUPPLEMENTARY MATERIAL}

The crystallographic data for $\mathrm{Cu}(\mathrm{BNHA})_{2}$ have been deposited with the Cambridge Crystallographic Data Centre (CCDC 910807).

\section{ACKNOWLEDGEMENTS}

This study was supported by the Russian Foundation for Basic Research (project 10-03-00003-a).

\section{REFERENCES}

[1] Buscarron, F. and Canela, J. (1974) Analytical uses of some n-nitroso-n-alkyl (or -n-cyclo-alkyl)hydroxylamines: Part II. Solvent extraction of metal hexahydrocupferrates. Analytica Chimica Acta, 70, 113-120. doi:10.1016/S0003-2670(01)82916-0

[2] Buscarron, F. and Canela, J. (1974) Analytical uses of some N-nitroso-N-alkyI (or -N-cycloalkyl)-hydroxylamines: Part III. N-Nitroso-N-cycIooctylhydroxylamine, N-nitroso-Ncyclododecylhydroxyl-amine and $\mathrm{N}$-nitroso-N-isopropyl- hydroxylamine. Analytica Chimica Acta, 71, 468-471. doi:10.1016/S0003-2670(01)85455-6

[3] Brown, J. (1917) The use of cupferron (phenylnitrosohydroxylamine ammonium) in: I. The qantitative separation of zirconium, titanium, iron, manganese and aluminum. II. The analysis of zircon and baddeleytte. Journal of the American Chemical Society, 39, 2358-2366. doi:10.1021/ja02256a013

[4] Párkányi, L., Kálmán, A., Deák, A., Venter, M. and Haiduc, I. (1999) A new inorganic (carbon-free) chelate ring: $\mathrm{SnO}_{2} \mathrm{~N}_{2}$. Eight-coordinated tin (IV) in $\mathrm{Sn}\left(\mathrm{O}_{2} \mathrm{~N}_{2} \mathrm{Ph}\right)_{4}$ and a self-assembled 20-membered macrocycle in $\left[\mathrm{Me}_{3} \mathrm{Sn}\left(\mathrm{O}_{2} \mathrm{~N}_{2} \mathrm{Ph}\right)\right]_{4}$. Inorganic Chemistry Communications, 2, 265-268. doi:10.1016/S1387-7003(99)00062-3

[5] Abraham, M.H., Bullock, J.I., Garland, J.H.N., Golder, A.J., Harden, G.J., Larkworthy, L.F., Povey, D.C., Riedl, M.J. and Smith, G.W. (1987) Copper and iron(III) complexes of N-nitroso-N-alkyl hydroxylamines, and the XRay crystal structures of bis(N-nitroso $\mathrm{N}$-isopropylhydroxylaminato) copper(II) and tris(N-nitroso-N-isopropyl hydroxylaminato) iron(III). Polyhedron, 6, 1375-1381. doi:10.1016/S0277-5387(00)80898-0

[6] Basson, S.S., Ledipoldt, J.G., Roodt, A. and Venter, J.A. (1992) Structure of carbonyl(N-hydroxy-N-nitrosobenzenaminato-O,O')(4-methyl-2,6,7-trioxa-1-phosphabicyclo[2.2.2] octane)rhodium(I). Acta Crystallographica Section C, 48, 171-173. doi:10.1107/S0108270191008223

[7] Ahmed, M., Edwards, A.J., Jones, C.J., McCIeverty, J.A., Rothin, A.S. and Tate, J.P. (1988) Metal complexes of Naryl-N-nitrosohydroxylamines: Cleavage of N-N bonds to give metal nitrosyl species and organonitrogen compounds, and the crystal structure of $\left[\mathrm{RhCl}_{2}\left\{\mathrm{ONN}\left(\mathrm{C}_{6} \mathrm{H}_{4} \mathrm{Me}-\mathrm{p}\right) \mathrm{O}\right\}\right.$ $\left.\left(\mathrm{H}_{2} \mathrm{O}\right)\left(\mathrm{PPh}_{3}\right)\right] \cdot 0.5 \mathrm{Me}_{2} \mathrm{CO}$. Journal of the Chemical Society, Dalton Transactions, 257-263. doi:10.1039/dt9880000257

[8] Najafi, E., Amini, M.M. and Ng, S.W. (2011) Bis $(\mu-\mathrm{N}-$ nitroso-N-phenylhydroxylaminato)- $\kappa^{3} \mathrm{O}, \mathrm{O}^{\prime}: \mathrm{O}^{\prime} ; \kappa^{3} \mathrm{O}^{\prime}: \mathrm{O}, \mathrm{O}^{\prime}-$ bis[(Nnitroso-N-phenylhydroxylaminato- $\left.\left.\kappa^{2} \mathrm{O}, \mathrm{O}^{\prime}\right) \mathrm{lead}(\mathrm{II})\right]$. Acta Crystallographica Section E, 67, m377. doi:10.1107/S1600536811006775

[9] Najafi, E., Amini, M.M. and Ng, S.W. (2011) Bis(Nnitroso-N-phenylhydroxylaminato- $\left.\kappa^{2} \mathrm{O}, \mathrm{O}^{\prime}\right)(1,10$-phenanthroline- $\left.\kappa^{2} \mathrm{~N}, \mathrm{~N}^{\prime}\right)$ lead(II). Acta Crystallographica Section E, 67, m378. doi:10.1107/S1600536811006787

[10] Tamaki, K. and Okabe, N. (1998) Diaquabis[N-(1-naphthyl)N-nitrosohydroxylaminato-O,O']cobalt(II). Acta Crystallographica Section C, 54, 195-197. doi:10.1107/S0108270197013620

[11] Okabe, N. and Tamaki, K. (1995) Dimethanolbis(N-nitrosoN-phenylhydroxylaminato-O,O')nickel(II). Acta Crystallographica Section C, 51, 2004-2005. doi:10.1107/S0108270195005816

[12] Van der Helm, D., Merritt Jr., L.L., Degeilh, R. and MacGillavry, C.H. (1965) The crystal structure of iron cupferron $\mathrm{Fe}\left(\mathrm{O}_{2} \mathrm{~N}_{2} \mathrm{C}_{6} \mathrm{H}_{5}\right)_{3}$. Acta Crystallographica, 18, 355-362. doi:10.1107/S0365110X65000816

[13] Bolboaca, M., Cîntă S., Venter, M., Deak, A., Haiduc, I., Cozar, O., Iliescu, T., Rösch, P. and Kiefer, W. (2000) Vi- 
brational behavior of transition metal cupferronato complexes: Raman studies on cobalt(II) cupferronato derivatives. Spectroscopy Letters, 33, 857-865. doi:10.1080/00387010009350162

[14] Pavel, I., Cîntă S., Venter, M., Deak, A., Haiduc, I., Rösch, P., Cozar, O. and Kiefer, W. (2000) Vibrational behavior of transition metal cupferronato complexes. Raman and SERS studies on nickel(II) cupferronato complexes. Vibrational Spectroscopy, 23, 71-76. doi:10.1016/S0924-2031(99)00086-7

[15] Tamaki, K. and Okabe, N. (1996) Manganese cupferronate. Acta Crystallographica Section C, 52, 1612-1614. doi:10.1107/S0108270196002661

[16] McGill, A.D., Zhang, W., Wittbrodt, J., Wang, J., Schlegel, H.B. and Wang, P.G. (2000) Para-substituted N-nitroso$\mathrm{N}$-oxybenzenamine ammonium salts: A new class of redox-sensitive nitric oxide releasing compounds. Bioorganic \& Medicinal Chemistry, 8, 405-412. doi:10.1016/S0968-0896(99)00300-4

[17] Shiino, M., Watanabe, Y. and Umezawa, K. (2001) Synthesis of N-substituted N-nitrosohydroxylamines as inhibitors of Mushroom Tyrosinase. Bioorganic \& Medicinal Chemistry, 9, 1233-1240. doi:10.1016/S0968-0896(01)00003-7

[18] Shiino, M., Watanabe, Y. and Umezawa, K. (2003) Synthesis and tyrosinase inhibitory activity of novel Nhydroxybenzyl-N-nitrosohydroxylamines. Bioorganic Chemistry, 31, 129-135. doi:10.1016/S0045-2068(03)00026-9
[19] Zyuzin, I.N., Nechiporenko, G.N., Golovina, N.I., Trofimova R.F. and Loginova, M.V. (1997) Synthesis and structure of di(non-azoxy) formals and some related Nalkyl-N'-alkoxydiazene N-oxides. Russian Chemical Bulletin, 46, 1421-1429. doi:10.1007/BF02505678

[20] Beck, M.T. and Nadypal, I. (1989) Chemistry of complex equilibria. Akad. Kiado, Budapest.

[21] APEX2 (Version 2008. 6-1), SAINT (V7.60A), SADABS (Version 2008/1), XPREP (Version 2008/2) (2005-2009) Bruker AXS Inc., Madison.

[22] Sheldrick G.M. (2008) A short history of SHELX. Acta Crystallographica Section A, 64, 112-122. doi:10.1107/S0108767307043930

[23] Thakur, N.V., Kartha, V.B., Kaneka, C.R. and Marthe, V.R. (1972) Infrared spectra of cupferron and some rare earth cupferrates, Journal of Inorganic and Nuclear Chemistry, 34, 2831-2836. doi:10.1016/0022-1902(72)80589-X

[24] Fochi, G., Floriani, C., Chiesi-Villa, A. and Guastini, C. (1986) Notes. Insertion of nitrogen oxide into a zirconium-carbon bond: Reaction of dialkylbis(cyclopentadienyl)zirconium(IV) complexes with nitrogen oxide. Journal of the Chemical Society, Dalton Transactions, 445447. doi:10.1039/dt9860000445

[25] Allen, F.H., Kennard, O. and Taylor, R. (1983) Systematic analysis of structural data as a research technique in organic chemistry. Accounts of Chemical Research, 16, 146-153. doi:10.1021/ar00089a001 